\title{
PENINGKATAN PEMAHAMAN GERAKAN HIDUP SEHAT MASYARAKAT TERHADAP COVID-19 DI WIJIREJO PANDAK BANTUL
}

\author{
Dina Rohmah ${ }^{1}$, Dominicus Danardono Dwi Prija Tjahjana ${ }^{2}$, Suyitno $^{2}$, Syamsul Hadi $^{2}$ \\ ${ }^{1}$ Statistika Fakultas Matematika dan Ilmu Pengetahuan Alam Universitas Sebelas Maret \\ ${ }^{2}$ Teknik Mesin Fakultas Teknik Universitas Sebelas Maret \\ syamsulhadi@ft.uns.ac.id
}

\begin{abstract}
Abstrak
Kuliah Kerja Nyata (KKN) UNS tanggap Wabah COVID-19 merupakan bentuk pengabdian mahasiswa kepada masyarakat yang dilaksanakan di berbagai wilayah di Indonesia berdasarkan domisili masing-masing mahasiswa. Kegiatan KKN UNS Era COVID-19 yang dilaksanakan di Dusun Karang Kauman Kelurahan Wijirejo Kecamatan Pandak Kabupaten Bantul ini dalam rangka membantu pemerintah untuk mempercepat penanganan wabah COVID-19 dan memberikan pemahaman secara rinci mengenai COVID-19. Berbagai program kerja untuk menunjang berjalannnya kegiatan KKN ini pun telah dilaksanakan seperti memberikan edukasi tentang pentingnya menerapkan protokol kesehatan selama wabah covid-19 kepada masyarakat secara online maupun offline (pemberian brosur), program pembagian masker dan handsanitizer, pengadaan fasilitas cuci tangan, dan bimbingan pembuatan masker yang bertujuan agar masyarakat selalu menggunakan masker saat pergi, rajin mencuci tangan, dan selalu menerapkan protokol kesehatan di manapun. Sebagai hasil kegiatan KKN, semua program kegiatan dapat berjalan dengan lancar dan berhasil. Masyarakat memberikan tanggapan positif dan merasa terbantu dengan adanya kegiatan ini. Dengan program KKN ini diharapkan masyarakat Dusun Karang Kauman dapat selalu menerapkan kebiasaan Pola Hidup Bersih dan Sehat (PHBS) dan selalu menerapkan protokol kesehatan agar dapat memutus mata rantai penyebaran COVID-19.
\end{abstract}

Kata Kunci : KKN UNS, Covid-19, pemahaman masyarakat, Karang Kauman, Bantul

\section{PENDAHULUAN}

Perkembangan kasus virus Covid-19 di Indonesia masih terus meningkat sampai sekarang dengan penambahan kasus perharinya yang terbilang cukup banyak. Berdasarkan data yang diperoleh dari website resmi Gugus Tugas Percepatan Penanganan covid-19, kasus positif covid-19 di Indonesia sudah mencapai 18.010 orang, sebanyak 4.324 sudah dinyatakan sembuh dan sebanyak 1.191 dinyatakan sudah meninggal sampai 18 Mei 2020 ini. Hal ini tentunya perlu diperhatikan tersendiri bagi masyarakat untuk membekali pengetahuan mengenai bahaya dan cara pencegahan / penanganan virus covid-19. Pengetahuan memegang peranan penting dalam penentuan perilaku yang utuh karena pengetahuan akan membentuk kepercayaan yang selanjutnya dalam mempersepsikan kenyataan, memberikan dasar bagi pengambilan keputusan dan menentukan perilaku terhadap objek tertentu (Novita dkk, 2018)

Kabupaten Bantul merupakan salah satu kabupaten di Provinsi DI Yogyakarta yang sudah terpapar virus covid-19 dan merasakan dampak akibat virus ini. Tercacat kasus virus covid-19 di Kabupaten Bantul sampai 18 Mei 2020 ini sebanyak 34 pasien dirawat, 17 sembuh dan 2 meninggal dunia 
(Gugus Tugas Percepatan Penanganan Penularan Infeksi Covid-19 Pemerintah Kabupaten Bantul). Jumlah kasus virus covid-19 tersebut sudah terbilang banyak untuk lingkup kabupaten. Menurut Gugus Tugas Percepatan Penanganan Penularan Infeksi Covid-19 Pemerintah Kabupaten Bantul (2020) di Kecamatan Pandak sendiri sudah terkonfirmasi sebanyak 1 orang positif dan 11 Orang Dalam Pemantauan (ODP). Hal ini tentunya perlu pencegahan dini agar penyebaran virus tidak semakin meluas. Khususnya di wilayah Karang Kauman, Wijirejo, Pandak, Bantul, DI Yogyakarta.

Berbagai kebijakan telah diberlakukan oleh pemerintah guna memutus mata rantai penyebaran virus, namun pada kenyataannya masyarakat masih menghadapi berbagai macam tantangan. Banyak masyarakat yang belum menerapkan physical distancing, perilaku hidup bersih dan sehat (PHBS), dan stay at home. Terlebih lagi, masih banyak masyarakat sekitar yang masih bepergian keluar rumah tanpa menggunakan masker dan juga belum terlalu paham mengenai penggunaan masker yang benar, mencuci tangan setelah bepergian, dan menerapkan protokol kesehatan untuk menghambat penyebaran covid-19. Dengan adanya beragam informasi tentang berbagai cara dalam mencapai pemeliharaan kesehatan, cara menghindari penyakit, maka akan meningkatkan pengetahuan masyarakat tentang hal tersebut (Dewi \& Wawan, 2011 : 18)

Menurut Depkes RI (2006) perilaku hidup bersih dan sehat (PHBS) pada hakikatnya merupakan perilaku pencegahan oleh individu atau keluarga dari berbagai penyakit. Salah satu sasaran penerapan program PHBS adalah pada tatanan rumah tangga, yang bertujuan untuk meningkatkan derajat kesehatan keluarga dan produktivitas kerja setiap anggota keluarga. Dalam permasalahan ini penting sekali untuk menumbuhkan kesadaran dan partisipasi aktif masyarakat mengenai pentingnya sosial distancing dan penerapan perilaku hidup bersih dan sehat (PHBS). Faktor pencegahan penularan menitikberatkan pada penanggulangan faktor Risiko penyakit seperti lingkungan dan perilaku (Novita dkk, 2018)

Oleh karena itu Kuliah Kerja Nyata (KKN) Covid-19 ini mengambil tema tentang supporting pemahaman masyarakat terhadap Covid-19 dengan tujuan untuk memberikan edukasi tentang bahaya covid-19 dan penularannya, pemahaman tentang pentingnya physical/ sosial distancing, pemahaman tentang Perilaku Hidup Bersih dan Sehat (PHBS) melalui cuci tangan dan memakai masker, dan pemahaman tentang pentingnya stay at home kepada warga khususnya warga di Dusun Karang Kauman karena masih ada warga yang belum menaati kebijakan pemerintah untuk mencegah covid seperti menjaga jarak, memakai masker ketika bepergian, dll.

\section{METODE}

Secara garis besar metode yang digunakan adalah edukasi dan pemberian bantuan. Edukasi dilakukan dengan program kegiatan sebagai berikut: 1. Edukasi gerakan physical/social distancing, gerakan Perilaku Hidup Bersih dan Sehat (PHBS) dan gerakan stay at home; 2 . Edukasi dan bimbingan pembuatan masker kain kepada ibu-ibu dasawisma; dan 3. Pembuatan tutorial video tentang pembuatan masker kain, dan handsanitizer alami. Sedangkan pemberian bantuan berupa: 1. Pengadaan fasilitas cuci tangan umum dan pengisian air tempat cuci tangan; 2. Program pembagian masker kain; dan 3. Program penanaman bibit pohon.

\section{HASIL DAN PEMBAHASAN}

Program kerja kegiatan KKN UNS Tanggap Wabah COVID-19 telah dilaksanakan di Dusun Karang Kauman, Wijirejo, Pandak, Bantul, DI Yogyakarta. Adapun Program kerja yang sudah dilaksanakan antara lain sebagai berikut.

\section{Edukasi gerakan physical/ sosial distancing, gerakan Perilaku Hidup Bersih dan Sehat (PHBS) dan gerakan stay at home}

Program yang telah dilaksanakan dalam KKN UNS covid-19 ini yaitu edukasi tentang pencegahan covid-19 kepada warga Dusun Karang Kauman agar dapat memutus mata rantai penyebaran virus ini. Program tersebut dipilih dengan alasan karena masih banyak warga yang belum memahami dan mengetahui tentang aturan pencengahan covid19 dan protokol kesehatan yang benar. Oleh karena itu, pengetahuan/pemahaman warga masyarakat sangat dibutuhkan untuk mengambil suatu tindakan dan perilaku dalam menghadapi wabah covid-19 ini dengan bijak dan tepat.

Pemberian edukasi tentang pencegahan covid-19 ini dilaksanakan dengan cara menyebarkan berbagai informasi seputar covid-19 seperti gejala dan tanda-

$$
\text { Lingkungan Hidup dan Kebencanaan }
$$


tanda orang terkena covid-19, cara penularan virus, cara memakai masker yang benar, perbedaan status orang dalam kasus covid-19, pentingnya menjaga jarak dan memakai masker, protokol kesehatan saat bepergian dan belanja bahkan sampai informasi tentang new normal yang tentunya dikemas secara menarik dalam gambar beranimasi agar masyarakat cepat paham, tertarik, dan tentunya dapat menerapkannya. Penyebarluasan informasi dilakukan secara online melalui WhatsApp dan instagram dan diadakan setiap 4 hari sekali secara berkala, lihat Gambar 1 dan Gambar 2. Sedangkan untuk penyebaran informasi secara offline dilaksanakan dengan menempelkan berbagai poster menarik mengenai COVID-19 di tempat-tempat umum dan strategis seperti di Gambar 3. Dengan adanya poster tersebut diharapkan masyarakat dapat membaca dan melihat informasi yang tertuang di dalamnya bahkan harus menerapkannya dalam kehidupan.

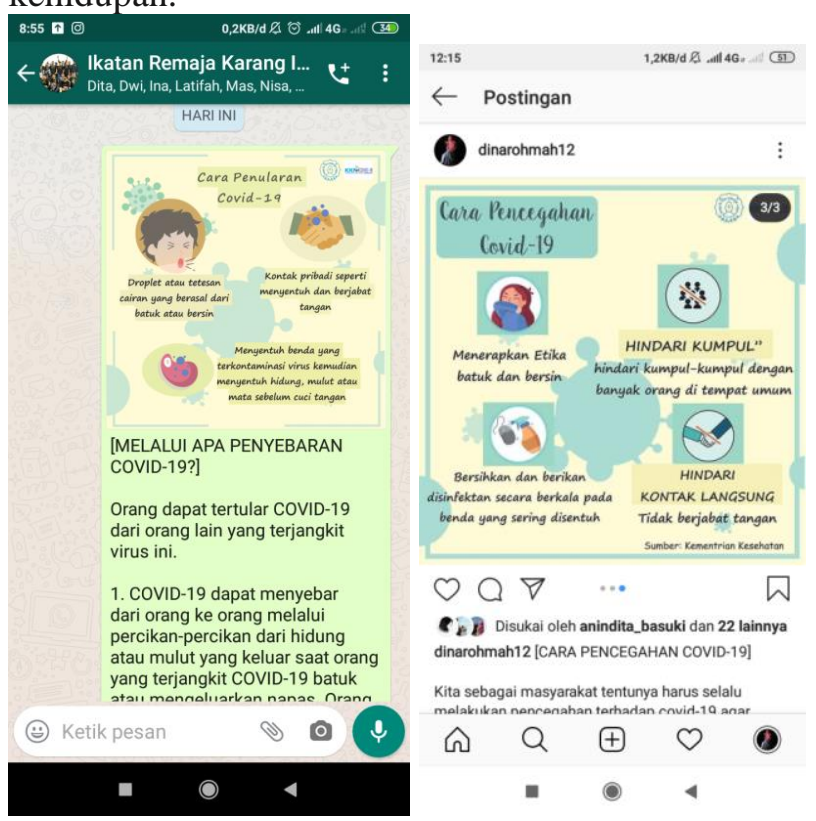

Gambar 1. Penyebaran informasi melalui WAG Karang Taruna Dusun Karang Kauman dan Story WhatsApp

Faktor pendukung dalam pemberian edukasi tentang covid-19 secara online ini yaitu terdapat banyak warga masyarakat didominasi oleh kaum remaja yang sudah mempunyai aplikasi WhatsApp dan Instagram. Hal ini tentunya membuat informasi dapat tersebarluaskan tidak hanya kepada warga
Dusun Karang dan berdampak pada banyak masyarakat yang mengetahui informasi tersebut dan dapat mengurangi penyebaran covid-19. Banyak warga yang memberikan respon positif terhadap penyebaran informasi secara online ini.

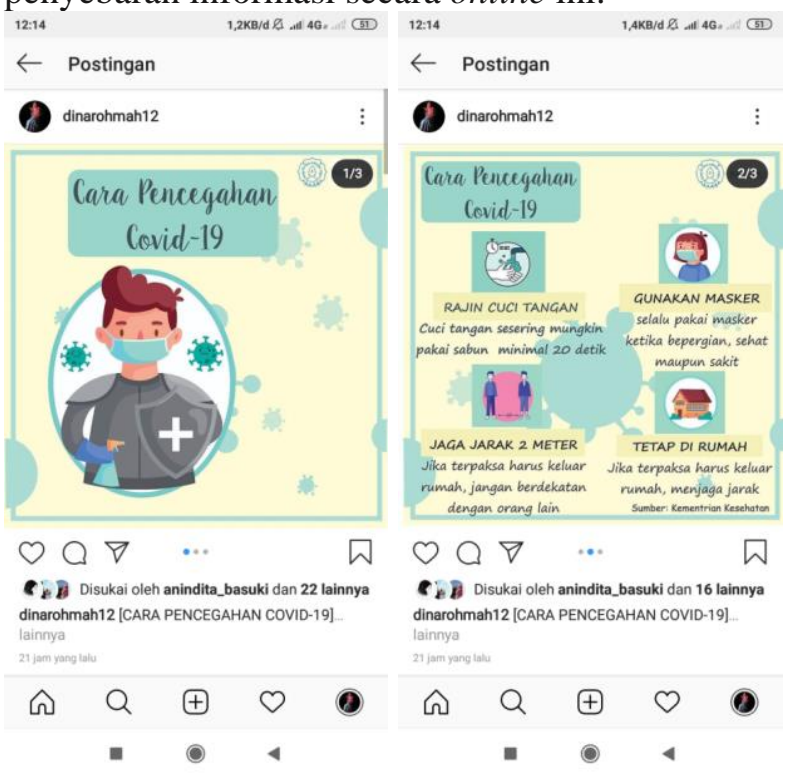

Gambar 2. Penyebaran informasi melalui Instagram

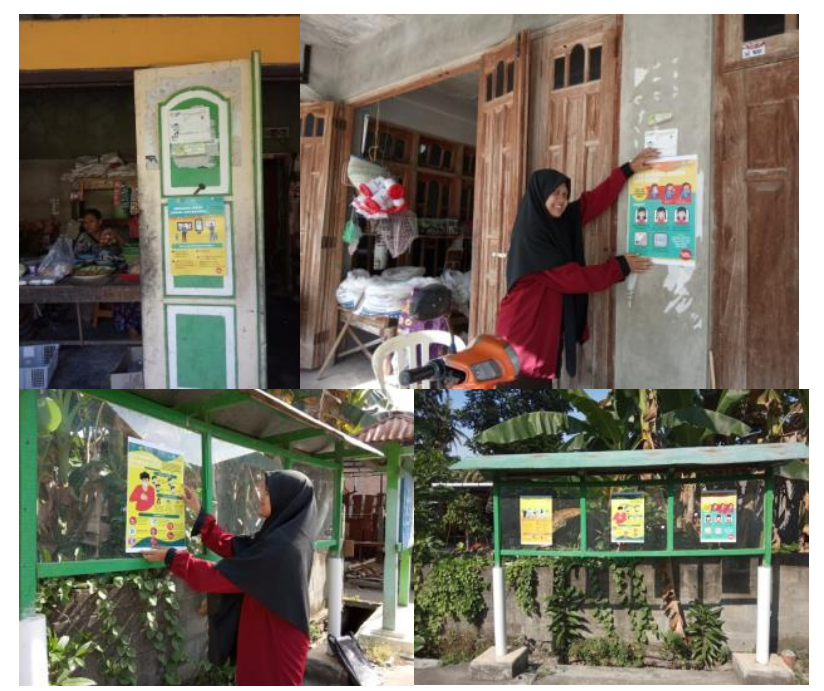

Gambar 3. Penyebaran Informasi dengan menempelkan poster di tempat-tempat umum

Sedangkan hambatan dalam pemberian edukasi ini diantaranya yaitu terdapat warga yang belum mempunyai smartphone. Hal tersebut menyebabkan beberapa warga tidak mendapatkan informasi seputar covid, namun hal tersebut ditangani dengan program KKN lain yaitu edukasi secara offline.

Lingkungan Hidup dan Kebencanaan

654 
Selain itu, hambatan lain yang muncul dalam penyebaran informasi melalui WAG, belum adanya respon yang signifikan dari masyarakat sendiri.

Hasil yang dicapai dalam program penyebaran informasi, seperti yang disampaikan di Gambar 1 dan Gambar 2, melalui Instagram ini yaitu masyarakat mendapat edukasi dan informasi seputar covid-19 secara online yang tentunya masyarakat setidaknya membaca dan melihat informasi yang disebarkan dan diharapkan masyarakat dapat selalu menerapkan informasi yang disebarkan agar dapat memutus mata rantai penyebaran covid-19. Dalam kegiatan penempelan poster di tempat umum, setelah poster ditempelkan, masyarakatpun mulai tertarik untuk membaca dan melihat isi poster.

\section{Edukasi dan bimbingan pembuatan masker kain kepada beberapa ibu-ibu dasawisma \\ Program edukasi ini memberikan bimbingan} pembuatan masker kain sembari memberikan edukasi bersama ibu-ibu dasawisma. Kegiatan ini menitikberatkan pada keefektifan pembuatan masker sendiri untuk mengisi kekosongan waktu saat di rumah. Program ini tentunya didukung dengan berbagai alat penunjang yang telah disediakan terlebih dahulu seperti kain, benang, jarum, karet elastis, dan gunting. Masker kain yang dibuatpun tentunya mudah dipraktikkan di rumah masingmasing. Kegiatan ini dilaksanakan dengan mengumpulkan dan mendatangi rumah ibu-ibu dasawisma yang tentunya tetap menerapkan protokol kesehatan covid-19 seperti memakai masker dan jaga jarak.

Faktor pendukung alam program pembekalan pembuatan masker jahit tangan ini adalah banyaknya ibu-ibu yang sangat mahir menjahit manual memakai jarum dan benang dan hasilnyapun cukup bagus dan rapi sehingga bisa dipakai sendiri hasil jahitan masker kain tersebut. Sedangkan faktor penghambat dalam program kerja ini yaitu susahnya mencari waktu luang yang pas untuk mengumpulkan ibu-ibu dasawisma dikarenakan beberapa ibu-ibu masih bekerja dan sedang mengurus keperluan rumah tangga.

Hasil yang sudah tercapai dalam program kerja ini yaitu ibu-ibu dasawisma mendapatkan ilmu tentang cara membuat masker kain sendiri secara manual dan diharapkan bisa diterapkan secara berkala agar tidak perlu lagi membeli masker cukup membuat sendiri dirumah dengan tentunya dengan tarif yang lebih terjangkau seperti ditunjukkan di Gambar 4. Dalam program kerja ini masing-masing ibu-ibu mendapatkan 1 masker kain hasil jahitan sendiri dan beberapa ibu-ibu telah menggunakan masker tersebut setelah dicuci sebagai anjuran dari pemerintah ketika bepergian.

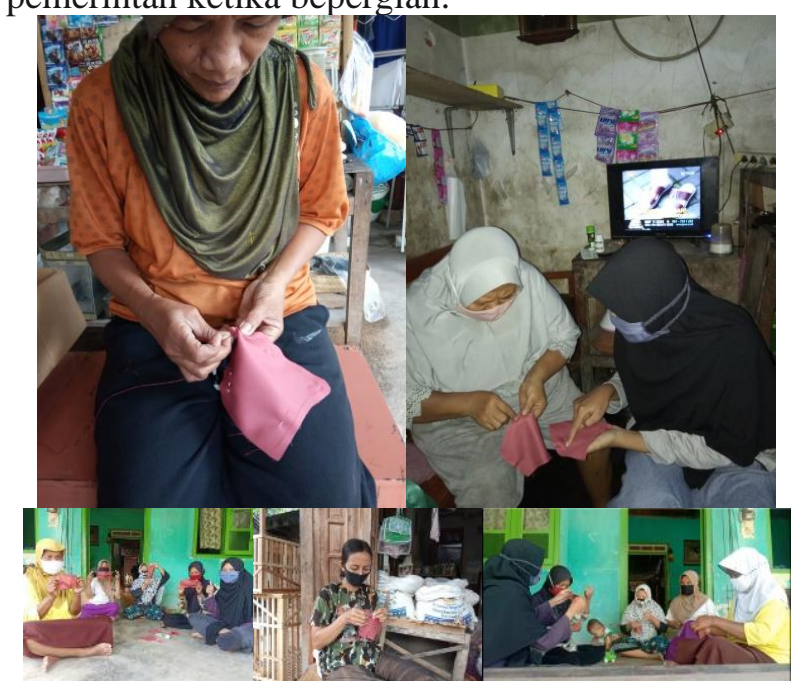

Gambar 4. Program Pembimbingan Pembuatan Masker Kain

\section{Pembuatan Tutorial Video tentang pembuatan masker kain, dan handsanitizer alami}

Program kerja ini merupakan kegiatan pembagian tutorial video cara pembuatan masker kain dan handsanitizer alami daun sirih yang disebarluaskan kepada masyarakat umum melalui instagram. Video tersebut dikemas dalam bentuk yang menarik agar masyarakat tertarik untuk melihat video tersebut. Selain itu, tentunya setelah program ini terlaksana banyak masyarakat yang bisa menerapkan pembuatan masker dan handsanitizer alami sendiri di rumah. Penyebaran video ini pun mendapat respon yang positif dari masyarakat karena proses pembuatannya mudah diterapkan sendiri di rumah.

Faktor pendukung dalam kegiatan pembagian video ini banyak masyarakat yang sudah menonton dan tertarik dengan video tersebut. Selain itu banyak masyarakat yang sudah menggunakan instagram walaupun didominasi oleh kaum remaja, namun responnya juga cukup baik tapi tentunya infromasi yang tersampaikan tersebarluaskan dengan luas. Sedangkan haabatan dalam kegiatan pembagian 
video tersebut adalah terdapat beberapa warga Dusun Karang Kauman yang berusi lanjut yang belum mempunyai instagram ataupun whatsApp jadi untuk mensosialisakan video pembuatan masker dan handsanitizer alami ini belum tersebarluaskan ke semua warga Dusun Karang Kauman.

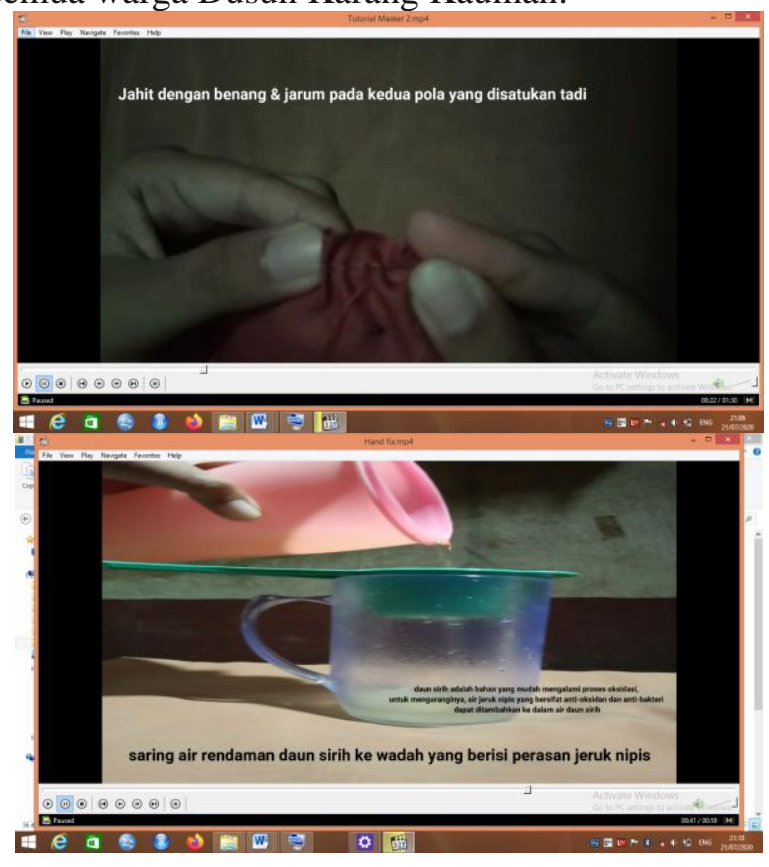

Gambar 5. Program Pembuatan Video Tutorial Pembuatan Masker Kain

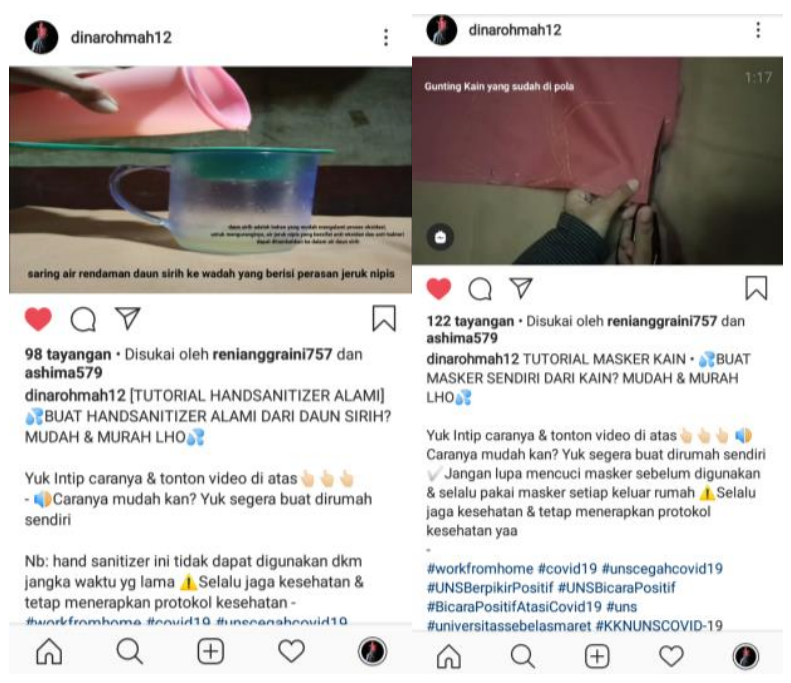

Gambar 6. Sosialisasi hasil pembuatan video melalui sosial media

Hasil yang sudah dicapai seperti dalam Gambar 5 dan Gambar 6 dalam program kerja ini adalah telah tersebarluaskan informasi video cara pembuatan masker kain dan handsanitizer alami secara luas yang didominasi oleh kaum remaja walaupun untuk penyebaran di Dusun Karang Kauman belum tersebarluakan secara maksimal.

\section{Pengadaan fasilitas cuci tangan umum dan pengisian air tempat cuci tangan}

Program kerja ini merupakan pemberian dan pembuatan fasilitas cuci tangan umum yang ditempatkan di beberapa tempat strategis (banyak masyarakat yang mampir/melewati). Pembuatan fasilitas cuci tangan umum ini di buat dari ember lalu dilubangi dan dipasangkan kran sehingga terbentuk seperti ember kran dispenser. Tentunya pemberian ember ini disertai dengan sabun cuci tangan, poster himbauan cuci tangan yang ditempelkan pada ember kran tersebut dan juga di tembok dekat ember ditempel poster cara mencuci tangan yang benar yang ditempel di tembok dekat ember. Terdapat 3 ember kran yang di pasang di 3 fasilitas umum yaitu di 2 warung kelontong dan masjid seperti disampaikan di Gambar 7. Masyarakatpun merasa terbantu dengan adanya fasilitas cuci tangan tersebut dan mendapatkan respon yang cukup baik dari masyarakat. Selain itu, dilaksanakan juga kegiatan pengisian air di ember cuci tangan agar dapat selalu terisi dengan air dan dapat digunakan masyarakat dengan baik. Dalam program ini, diharapkan banyak masyarakat khususnya masyarakat Dusun Karang Kauman yang selalu menerapkan Pola Hidup Bersih dan Sehat (PHBS) seperti contoh rutin mencuci tangan dengan sabun.

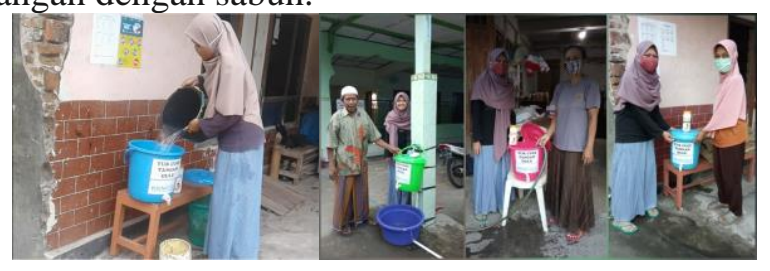

Gambar 7. Pembuatan fasilitas cuci tangan dan edukasi tentang protokol kesehatan Covid-19

Faktor pendukung yang ada adalah masyarakat merasa terbantu dengan adanya fasilitas cuci tangan umum ini, karena banyak masyarakat Dusun Karang Kauman yang belum mempunyai fasilitas cuci tangan di depan rumah. Sedangkan faktor penghambat adalah pemilihan tempat pemasangan ember kran ini cukup susah karena harus

Lingkungan Hidup dan Kebencanaan 656 
mempertimbangkan kebermanfaatan fasilitas cuci tangan ini bagi orang banyak dan tentunya akan digunakan secara berkelanjutan, jadi dipilihlah warung kelontong dan masjid yang banyak dilewati orang banyak. Setelah pemasangan fasilitas cuci tangan ini, banyak masyarakat yang mulai menggunakan fasilitas ini untuk cuci tangan bahkan anak-anakpun turut serta selalu mencuci tangan setelah dari warung sampai-sampai pernah isi air dalam ember dapat habis dalam 3 hari.

\section{Program Pembagian Masker Kain}

Program pembagian masker kain ini merupakan kegiatan pembagian masker kain secara gratis kepada warga Dusun Karang Kauman dan disertai dengan edukasi/pemahaman tentang informasi seputar covid-19 dan protokol kesehatan selama wabah covid-19 melalui brosur yang dikemas secara menarik dan mengandung informasi yang padat, jelas, dan mudah dimengerti. Pemberian masker ini dilaksanakan dengan mendatangi rumahrumah warga secara bergantian dan beberapa warga juga mendapatkan handsanitizer dengan selalu menerapkan protokol kesehatan yang ada seperti memakai masker, jaga jarak, dan selalu mencuci tangan setelah selesai berkegiatan. Dengan adanya program ini, diharapkan masyarakat selalu menggunakan masker ketika bepergian ke luar rumah dan selalu menerapkan protokol kesehatan, lihat Gambar 8.

Faktor pendukung dalam kegiatan ini adalah banyaknya respon positif dari masyarakat. Masyarakat merasa senang dengan adanya program ini, karena terdapat beberapa masyarakat yang mempunyai jumlah masker belum memadai yang bisa digunakan secara bergantian setelah bepergian keluar rumah.

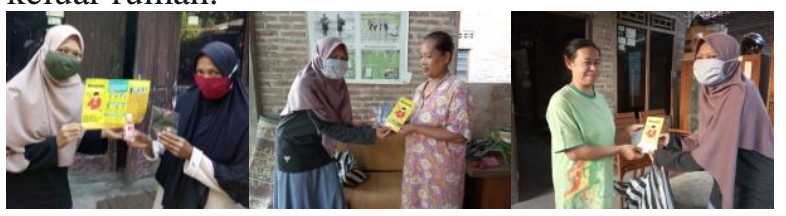

Gambar 8. Pembagian masker kain disertai edukasi tentang protokol kesehatan Covid-19

Hasil yang telah dicapai dalam kegiatan ini antara lain yaitu masyarakat merasa terbantu dengan adanya masker ini. Selain itu, dengan adanya edukasi yang telah diberikan masyarakat lebih paham tentang protokol kesehatan selama covid-19 ini dan tentunya harus selalu waspada tetapi jangan panik. Masyarakatpun mulai menggunakan masker pemberian dari program KKN ini.

\section{Program penanaman bibit pohon}

Program penanaman bibit pohon ini merupakan program tambahan yang muncul selama kegiatan KKN. Penanaman bibit ini memilih pohon cabai dan pepaya karena cabai merupakan sayuran yang sering digunakan masyarakat untuk memasak dan pepaya juga bisa menjadi salah satu masakan yang dapat dikonsumsi masyarakat selama wabah covid-19 ini, karena saat wabah covid-19 ini perekonomian masyarakat juga sedang menurun. Tujuan dari program ini yaitu membiasakan masyarakat untuk menanam sayuran agar dapat dijadikan sebagai masakan untuk makan dan agar masyarakat mempunyai waktu yang produktif selama berada di rumah saja.

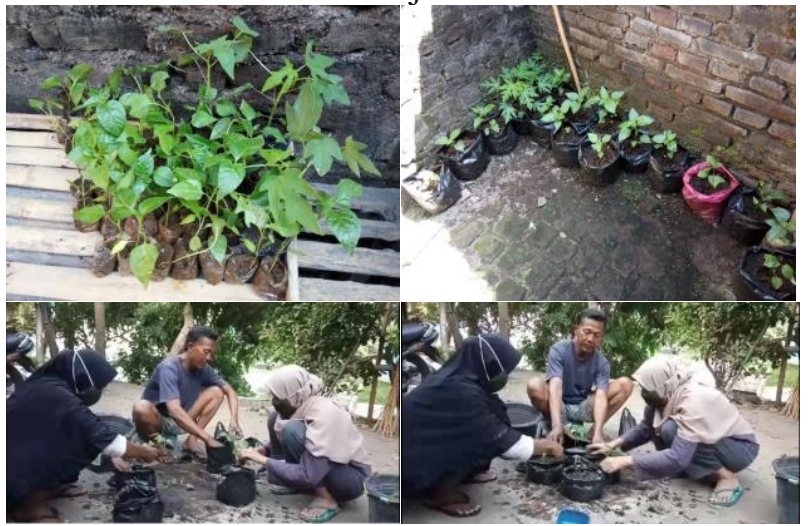

Gambar 9. Penanaman Bibit pohon cabai dan pepaya

Faktor pendukung dalam program ini adalah pekerjaan masyarakat yang mayoritas adalah petani, hal ini tentunya membuat program ini mudah berjalan karena masyarakat sudah terbiasa untuk bercocok tanam di sawah, walapaun dalam program ini memanfaatkan media polybag sebagai wadah, namun untuk proses pembuatannya mirip dengan bercocok tanam di sawah. Hasil yang telah dicapai dari program ini yaitu penanaman bibit cabai dan pepaya yang cukup berhasil dan dapat tumbuh pada mestinya.

Semua kegiatan yang telah dilakukan selama program KKN dilakukan sosialisasi melalui dua media yaitu media tulis dan media video. Untuk media tulis hasil KKN sudah disampaikan di laman

Lingkungan Hidup dan Kebencanaan 
berikut https://www.kompasiana.com/dinarohmah /5f0075c6d541df1ed82b5fa6/mahasiswa-kkn-unsera-covid-19-adakan-bimbingan-masker-kainkepada-ibu-ibu-dasasisma-dusun-karang-kaumanwijirejo-pandak-bantul. Sedangkan video kegiatan disampaikan via channel Youtube berikut https://youtu.be/DRyWzRL1Qec. Upaya ini dilakukan agar proses edukasi yang sudah dilakukan selama kegiatan KKN dapat selalu dipelajari oleh masyarakat dan bermanfaat terus selama tayangan dan tulisan tersebut dibaca dan ditonton oleh masyarakat luas.

\section{KESIMPULAN}

Berdasarkan Program-program kerja KKN UNS tanggah wabah COVID-19 yang telah dilaksanakan Mei-Juni 2020 dapat diambil kesimpulan sebagai bahan evaluasi pemerintah dalam menangani wabah COVID-19 dan juga saran yang dapat membantu pemerintah dalam menangani wabah COVID-19 ini.

Program kerja selama KKN UNS tanggah wabah COVID-19 bertujuan untuk memberikan pemahaman atau edukasi kepada masyarakat khususnya masyarakat Dusun Karang Kauman RT 05 mengenai informasi yang valid dan benar tentang COVID-19 mulai dari pentingnya memakai masker, jaga jarak, dan menerapkan protokol kesehatan. Edukasi yang telah dilaksanakan mendapatkan tanggapan yang positif dari masyarakat dan masyaratpun mulai paham dan menerapkan tentang aturan selama covid-19.

Program utama yang dilaksanakan fokus kepada penanaman pemahaman kepada masyarakat untuk bertindak sesuai aturan yang telah dianjurkan pemerintah selama covid-19 ini, dengan memberikan dukungan berupa aksi nyata dalam membantu warga mewujudkan anjuran dari pemerintah seperti memberikan masker, pengadaan fasilitas cuci tangan, dan penempelan poster. Hal tersebut tentunya mendapatkan respon positif dari masyarakat dengan masyarakat mulai memakai masker saat bepergian dan rajin mencuci tangan dengan sabun.

Terdapat beberapa program kerja yang belum melibatkan semua masyarakat Dusun Karang
Kauman contohnya program pembekalan pembuatan masker. Akan lebih baik jika program tersebut melibatkan semua masyarakat agar informasi yang disampaikan dapat merata.

Belum maksimalnya koordinasi dengan Kepala Dukuh dan Ketua RT mengenai program-program kerja yang akan dilaksanakan. Sebaiknya, untuk menyusun program kerja yang akan dilaksanakan perlu secara serius didiskusikan dengan Kepala Dukuh dan Ketua RT agar sesuai dengan kondisi dan kebutuhan yang masyakat perlukan dan tentunya program tersebut diharapkan memberikan manfaat bagi masyarakat.

\section{UCAPAN TERIMAKASIH}

Ucapan terimakasih disampaikan kepada Unit Pengelola KKN LPPM UNS yang telah memberikan kesempatan dan pendanaan untuk melakukan pengabdian kepada masyarakat melalui dana PNBP tahun 2020. Juga kepada masyarakat di Karang Kauman, Wijirejo, Pandak, Bantul, DI Yogyakarta yang mendukung program KKN berhasil, terkhusus kepada pengurus RT yang telah membimbing dan mengarahkan pelaksanaan KKN sehingga dapat berjalan dengan lancar.

\section{REFERENSI}

Depkes RI. (2006). Perilaku Hidup Bersih dan Sehat di Rumah Tangga. Jakarta: Depkes RI

Dewi, M. dan Wawan, A.(2011).Teori Dan Pengukuran Pengetahuan, Sikap dan Perilaku Manusia. Yogyakarta : Nuha Medika. ISBN 978602-95997-8-7

Gugus Tugas Percepatan Penanganan covid19 (2020). Diakses pada 18 Mei 2020 pukul 23.15. https://covid19.go.id/

Nur Wachida Novita, Christina Yuliastuti, dan Siti Narsih (2014). Tingkat Pengetahuan Tentang TB Paru Mempengaruhi Penggunaan Masker Di Ruang Paru Rumkital Dr. Ramelan Surabaya. Jurnal Ilmiah Kesehatan STIKES Hang Tuah. Vol 7. No. 12.

Pemkab Bantul (2020). Diakses pada Senin 18 Mei 2020 pukul 22.30. https://corona.bantulkab.go.id/

Lingkungan Hidup dan Kebencanaan 